\title{
Bound Morpheme Used In Al Jazeera News Entitled "Syria's Refugee Children: Futures Lost To The War" By Barbara Bibbo: A Morphology Perspective
}

\begin{tabular}{ccc}
\multicolumn{3}{c}{$\begin{array}{c}\text { Paramita Kusumawardhani } \\
\text { University of Bina Sarana Informatika, Indonesia } \\
\text { paramita.pmi@ bsi.ac.id }\end{array}$} \\
\hline Diterima & Direvisi & Disetujui \\
$09-08-2021$ & $16-09-2021$ & $28-09-2021$ \\
\hline
\end{tabular}

\begin{abstract}
The purpose of the research is to know about the use of bound morpheme in an article in Al Jazeera News, entitled, "Syria's Refugee Children: Futures Lost to the War" written by Barbara Bibbo. A bound morpheme is commonly used in some articles because it can change the meaning of the word itself. A bound morpheme is part of derivational morphology. Morphology itself means the study of morphemes which are the smallest significant units of grammar. A morpheme is the smallest unit in English linguistics which forms a word. There are two kinds of morpheme; they are free morpheme and bound morpheme. A morpheme that can stand on their own are called free, and ones that cannot are bound. A bound morpheme has two types; there is Derivational and inflectional morpheme. The data of the research was taken from an article in Al-Jazeera News. A qualitative descriptive method was used to do the research. The results of the research are there are 49 bound morphemes found in the article. 5 of them are derivational and 44 of them are inflectional.
\end{abstract}

\section{Keywords: Morphology, Morpheme, Bound Morpheme, Al-Jazeera}

\begin{abstract}
Abstrak:
Tujuan dari penelitian ini adalah untuk mengetahui penggunaan morfem terikat dalam sebuah artikel di $\mathrm{Al}$ Jazeera News yang berjudul, "Syria's Refugee Children: Futures Lost to the War" yang ditulis oleh Barbara Bibbo. Morfem terikat banyak digunakan dalam beberapa artikel karena itu dapat mengubah arti kata itu sendiri. Morfem terikat adalah bagian dari morfologi turunan. Morfologi itu sendiri berarti studi tentang morfem yang merupakan unit tata bahasa terkecil yang signifikan. Morfem adalah unit terkecil dalam linguistik bahasa Inggris yang membentuk sebuah kata. Ada ada dua macam morfem yaitu morfem bebas dan morfem terikat, morfem yang dapat berdiri sendiri disebut morfem bebas dan morfem tidak terikat, morfem terikat ada dua jenis yaitu morfem turunan dan morfem infleksional. penelitian ini diambil dari sebuah artikel di Al-Jazeera News. Metode penelitian yang digunakan adalah deskriptif kualitatif. Hasil penelitiannya terdapat 49 morfem terikat yang ditemukan dalam artikel tersebut. derivasional dan 44 di antaranya bersifat infleksional.
\end{abstract}

\section{INTRODUCTION}

Four skills in English must be mastered by students namely listening, speaking, reading, and writing. Especially for writing, (Thesis, Henisah, \& Faculty, 2021) defines that it is a skill of a writer to communicate information to a reader or group of readers. This skill can be realized by having the ability to apply the rule of the language to transfer the information to the readers effectively.

To communicate through articles, mastering the structures of language is needed. Structures of the language do not only occur in the sentence but also the word. It is related to the discussion of morphology. Morphology is a part of linguistics. (Kusumawardhani, 2018) stated that in linguistics, morphology refers to the mental system involved in word formation or to the branch of linguistics that deals with words, their internal structure, and how they are formed. A major way in which morphologists investigate words, their internal structure, and how they are formed is through the identification and study of morphemes, often defined as the smallest linguistic pieces with a grammatical function. It can be noted that knowledge about morphology also has a significant role in writing.

The morpheme is the main discussion in morphology. There are two kinds of morphemes they are free and bound. According to (Blevins et al., n.d.), the morphemes that can stand on their own are called free, and ones that cannot are bound. Bound morphemes are also called affixes which can be classified into prefix, infix, and suffix. English only has two kinds of bound morphemes namely prefixes and suffixes. There are 
no infixes in English. Bound morphemes are classified into two namely derivational and inflectional morphemes. Inflectional morphology is the relationship between word forms of a lexeme. While, derivational morphology is the relationship between lexemes of a word family, (Sukmacahyadi, 2018). Much deeper, inflectional and derivational can be recognized in the following ways:

\begin{tabular}{|l|l|}
\hline \multicolumn{1}{|c|}{ Inflectional } & \multicolumn{1}{c|}{ Derivational } \\
\hline Never changes category & Sometimes changes category \\
Adds grammatical meaning & Often adds lexical meaning \\
Important to syntax & Produces new lexemes \\
Usually fully productive & Range from unproductive to fully productive \\
& \\
\hline
\end{tabular}

Sources: Sukmacahyadi, 2018

Based on the explanation and table above, it can be concluded that bound morpheme is a part of morpheme which consists of inflectional and derivational. A bound morpheme is also usually used and found in texts to change the meaning of the words in the sentences to make the sentences easy to read and understand by the readers.

Inflectional word formation is wordformation that expresses grammatical distinctions like number (singular vs. plural); tense (present vs. past); person (first, second, or third); and case (subject, object, possessive), among others. It does not result in the creation of new lexemes, but merely changes the grammatical form of lexemes to fit into different grammatical contexts. It can be noted that inflectional affixes refer to the additional affixes (prefix or suffix) because of the influence of grammatical rules without changing the based meaning or word class.

\section{Definition of Morphology}

Concerning language, usually morphology is used to study the formation of words such as create a new word, combining two words into one, or specifying the origin of the word. Morphology has a lot of definitions from some experts. According to Carthy as cited in (Nurngaini, Hastuti, \& Andriani, 2019), "The word morphology is derived from the Greek word morphe meaning form and logos meaning science". It means morphology is a study about word formation.

(Aronoff \& Fudeman, n.d.) stated that morphology referred to the mental system involved in word formation or to the branch of linguistics that deals with words, their internal structure, and how they are formed. Morphology dealt with the structure of words. Knowing, knowingly, and unknowingly are kinds of derivational morphology. The base word is "know" and it is added with morphemes -ing, -ly, and un-.

According to (March et al., 2014), morphology is the study of investigating forms in language rather than depending on identifying words. Morphology plays an important role in the construction of linguistic units and structures. It is morphology that allows the language to adopt new words from the existing words (derivational morphology) or to change the grammatical aspect of a word according to its use in a specific context (inflectional morphology).

(Khan, Akram, \& Khan, 2016) explained that the study of morphology contains a thorough examination of several bits of language that combine to make a single linguistic unit, known as the 'word'. Linguistically these bits are called morphemes. A morpheme is a minimal unit of meaning or grammatical function. There are two sub-categories of morphemes, namely free and bound morphemes. Free morphemes can stand by themselves in isolation, e.g. boy, cat, dog, etc., while bound morphemes are always attached to free morphemes and never occur in isolation, e.g. ness in madness. The former contains lexical morphemes that have a dictionary meaning (like $a$ wall, book, fan, etc.) and functional morphemes that have grammatical functions to fulfill (like $a$, an, the, etc.). The latter contains derivational morphemes and inflectional morphemes. The main difference between the two is that derivational morphemes produce new words in a language by changing their word class, e.g. teach-teach-er, while inflectional morphemes indicate aspects of the grammatical function of a word and never change its grammatical category e.g. boy-boy-s.

From the explanation above, morphology is the study of the basic word and word formation. Created new words in a language, to describe, analyze, and modify existing words is some purpose of morphological processes.

\section{Definition of Morpheme}

A morpheme is an important component in word-formation. According to (Adisutrisno, 2013), "Morphology cannot be separated to linguistic terms for the most element unit of grammatical 
form. This element unit is called morpheme". Similarly, according to (Nurngaini et al., 2019), "Morpheme is a minimal unit of meaning or grammatical function". Concerning meaning, morpheme cannot be divided into smaller meaningful parts. One of the functions units grammatical used to indicate past tense. For example, the word reopened consists of three morphemes. One minimal unit of meaning is open, another minimal of meaning is re- meaning again, and a minimum unit grammatical function is $-e d$ indicating past tense.

The grammatical function of a morpheme is important, the meaning must be constant. Consider the English word lovely and Especially, end with the suffix $-l y$. Although using the same suffix, when add $-l y$ to the adjective especial, that change into an adverb. When we add -ly to the noun love, that creates an adjective. The conclusion, not all of the words ending with -ly change to be an adverb. What on the surface appears to be a single morpheme turns out to be two. One attaches to an adjective (especial) and creates an adverb, the other attaches to a noun (love) and creates an adjective.

According to Lieber as cited in (Jakarta, 2018), "Morpheme is the meaningful unit that is used to form words". It means, morpheme cannot be divided into smaller meaningful parts because a word is a smaller part in the sentence.

Based on the explanation above, it can be concluded that morpheme is an important component in word-formation. It is the meaningful unit that is used to form words.

\section{Definition of Bound Morpheme}

There are two types of morpheme; they are free morpheme and bound morpheme. There are two kinds of free morpheme; they are lexical and functional morpheme. Bound morpheme consists of two types; they are derivational morphemes and inflectional morphemes. Derivational morphemes are morphemes used to make new words but not necessarily in a change in a syntactic category, for example, the addition of derivational morphology re-changes the meaning of the word open if they are combined into reopening. Inflectional morphemes are morphemes to indicate grammatical functions (they never change the syntactic category). Here are the classifications of morphemes:

Diagram 1. The Classification of Morpheme

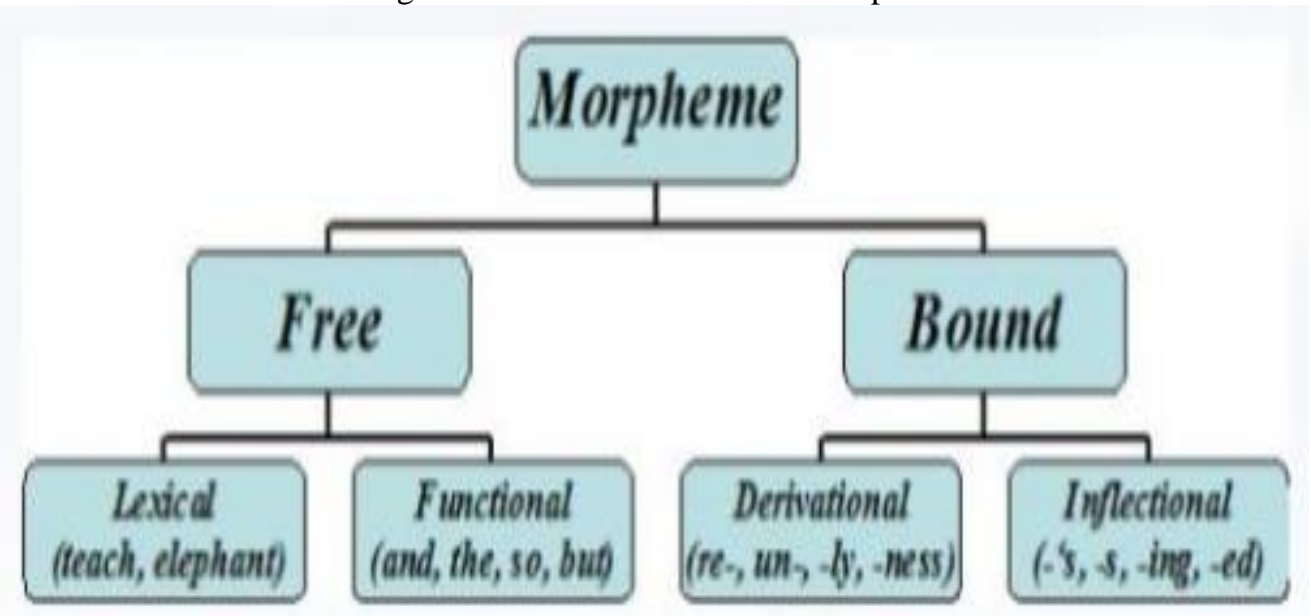

https://languageavenue.com/linguistics/general-linguistics/grammar-syntax/item/morphemes-in-english

Bound morphemes are a meaning-bearing unit of language, such as prefixes and suffixes that are attached to free morphemes. They cannot stand alone. The attachment modifies the free morphemes in such things as a number of the syntactic category. By adding derivational or inflectional can change the meaning of the word, the quantity of the noun, or the tense.

Examples:

\section{Adding Derivational}

Happy means senang

Un + happy = unhappy. It means tidak senang

Responsible means bertanggung jawab

$\mathrm{Ir}+$ responsible $=$ Irresponsible and it means tidak bertanggung jawab

Adding Inflectional

Pencil means one pencil

Pencil $+s=$ pencils and it means more than one pencil

Butterfly means one butterfly 
Butterfly + ies $=$ butterflies and it means more than one butterfly

She walks to her school every day. (It is used in the simple present)

She walked to her school this morning. (It is used in simple past)

Mother waters her plants every morning. (It is used in the simple present)

Mother watered her plants yesterday morning. (it is used in simple past)

\section{bound morphemes.}

Linguistics recognizes two classes of

a. The first class is called inflectional morphemes and their influence on a base word is predictable. Inflectional morphemes modify the grammatical class of words by signaling a change in number, person, gender, tense, and soon, but they do not shift the base form into another word class. When house changes to houses, it is still a noun even though you have to add the plural morphemes;

b. The second class of morphemes is derivational morphemes. They modify a word according to its lexical and grammatical class. They result in more profound changes in base words. The word style is a noun, but it is changed to stylish, then it becomes an adjective. In English, derivational morphemes include suffixes (e.g., ish, ous, er, y, en, and able) and prefixes (e.g., un, im, re, and ex).

It can be concluded that bound morpheme is adding prefixes or suffixes to the base words to change the meaning of the words, the quantity of the noun, or the tense. These changes need to make the words appropriate to be used in sentences in an article to be understandable by the readers.

\section{RESEARCH METHOD}

The method used in this research is descriptive qualitative. The descriptive method was used as (Best \& Kahn, 1995) explained that descriptive method is the method that tries to explain the symptoms relating to the recent situation. It consists of the effort of giving the note, the analysis, and the interpretation of the recent symptoms which have the characteristics as follows: try to give the fact, straight to the problem, and the recent variables aren't manipulated by the researcher.

The data was taken from an article in AlJazeera News entitled, Syria's Refugee Children: Futures Lost to the War. The article is then read, identified, classified, and analyzed to be recognized easily.

\section{FINDINGS AND DISCUSSIONS}

Here is the article which is discussed

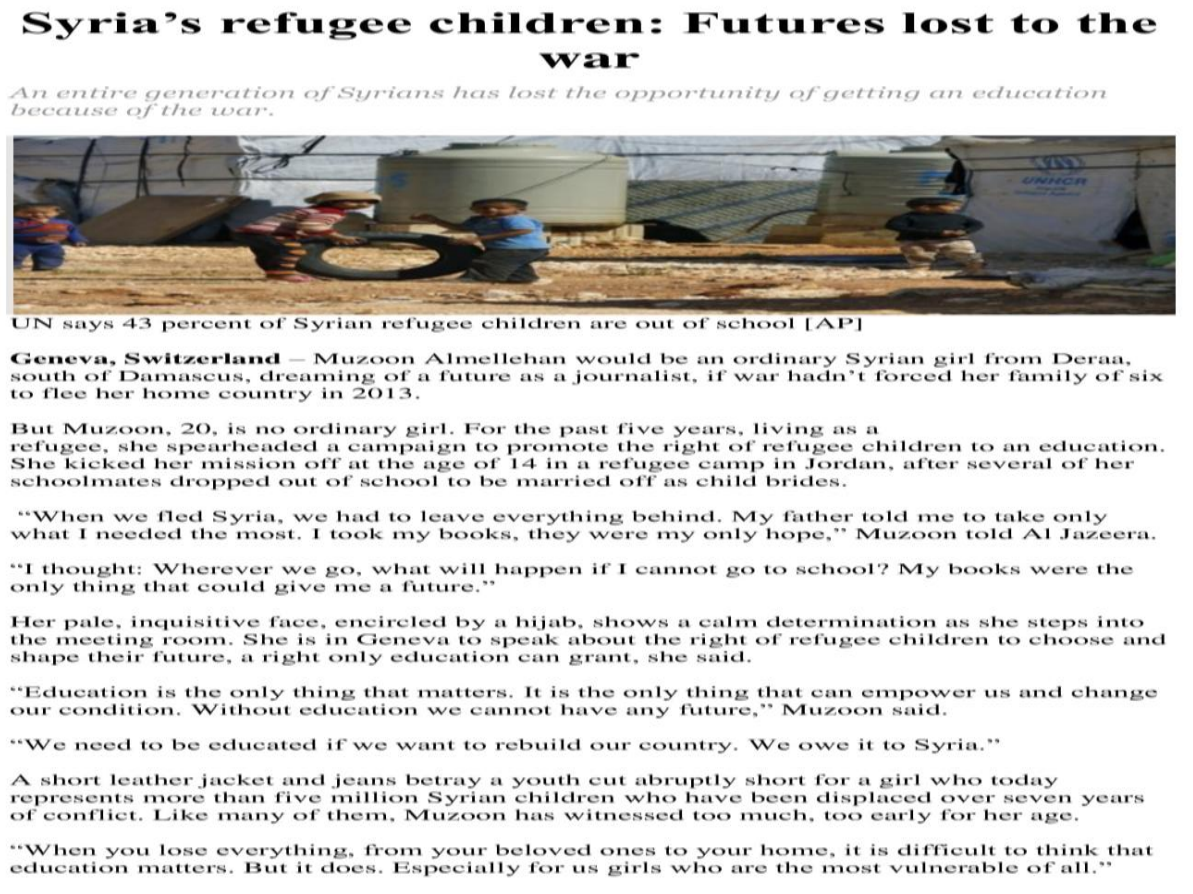

Picture 1. The Article 


\section{0 percent out of school}

According to the UN agencies, some 43 percent of Syrian refugee children in Turkey.

Poverty and dwindling financial means are making it almost impossible for families to get by in these countries. In a recent study conducted by UNICEF Jordan, more than 85 percent of refugees outside the camps - in host communities - live in poverty, struggling to meet their basic needs, including providing education for their children.

But it is difficult to envisage an improvement in the life and prospects of $S$ yrian refugee children. As the war becomes further protracted, the prospect of returning to a normal life for the 2.6 million Syrians in neighbouring countes and e $2.8 \mathrm{minion}$ internally displaced receive an education because of the war. "There has been a total disregard for the protection of children by all sides in this conflict," the parties in the conflict to do what they must to protect children as per the international law."

The first two months of this year have been especially bloody for children in Syria. UNICEF received reports of more than 1,000 children killed and seriously wounded since the year 361 were injuries and 910 deaths.

Some 961 children were recruited in combat.

Meanwhile, in refugee host countries nearly 10,000 Syrian refugee children are either unaccompanied or separated from their families. Many of these children are vulnerable to exploitation and child labour, because of a lack of legal documentation.

Left without any hope, as Syrians find themselves displaced multiple times, many families marry off their daughters as child brides to protect them from being kicnapped and abused, o war started, Muzoon said.

"I remember a 17-year-old girl, who came to tell me that she was to marry a man older than her father. I told her to convince her parents that an education would have given her a better "she recalled. "I told her to be brave. She didn't get married in the en and went back to school.

Muzoon campaigned relentlessly for three years in the Zaatari and Azraq refugee camps in Jordan, where her family had fled to the middle of clashes between government forces and the Free Syrian Army.

"In Syria, we had a normal, happy life. We had everything. Suddenly we found ourselves in a refugee camp. I hated it."

\section{'Nobody would tell us to go to school'}

Life in the camp was difficult, recalled Muzoon. Her family had to squeeze into a small tent with no running water or electricity. But she "didn't want to be negative", she said, so she looked for a school in order not to miss ninth grade.

"Nobody would tell us to go to school. It was totally voluntary, so many kids were not going or dropped out. So I started visiting the tents of the camps to publicise the school and encouraging children to join."

She was often scorned and sent away by parents and children alike, who thought marriage was their only way out of poverty.

"I knew how they felt, the horror and pain they had gone through, the events they witnessed are something they couldn't forget. For many of them education seemed an irrelevant thing."

But many children went back to school thanks to her encouragement. UNICEF supported Muzoon in her mission and made her the agency's youngest goodwill ambassador last year.

Geert Cappelaere, UNICEF's regional director for the Middle East and North Africa, has called on those fighting inside Syria and all those who have influence over them to put their arms down and stop the war on children.

"The children of Syria have been waiting for way too long. The world has failed the children of Syria so many times, it cannot keep failing them. History will judge us all if we do," Cappelaere said.

Sources: https://www.aljazeera.com/news/2018/4/11/syrias-refugee-children-futures-lost-to-thewar

Picture 2. The Article

There are some bound morphemes found in Al Jazeera News article. The findings are

Tabel 2. Derivational Bound Morpheme

\begin{tabular}{|l|l|l|}
\hline \multicolumn{1}{|c|}{ No. } & \multicolumn{1}{|c|}{ Word } & \multicolumn{1}{c|}{ Basic Word } \\
\hline 1. & Empower & Power \\
\hline 2. & Rebuild & Build \\
\hline 3. & Impossible & Possible \\
\hline 4. & Unrealistic & Realistic \\
\hline 5. & Uncommon & Common \\
\hline
\end{tabular}


Tabel 3. Inflectional Bound Morpheme

\begin{tabular}{|l|l|l|}
\hline No. & \multicolumn{1}{|c|}{ Words } & \multicolumn{1}{c|}{ Basic Words } \\
\hline 1. & Syrian & Syria \\
\hline 2. & Dreaming & Dream \\
\hline 3. & Journalist & Journal \\
\hline 4. & Living & Live \\
\hline 5. & Refugee & Refuge \\
\hline 6. & Education & Educate \\
\hline 7. & Married & Marry \\
\hline 8. & Inquisitive & Inquisition \\
\hline 9. & Determination & Determinate \\
\hline 10. & Educated & Educate \\
\hline 11. & Abruptly & Abrupt \\
\hline 12. & According & Accord \\
\hline 13. & Making & Make \\
\hline 14. & Improvement & Improve \\
\hline 15. & Protracted & Protract \\
\hline 16. & Neighbouring & Neighbour \\
\hline 17. & Internally & Internal \\
\hline 18. & Displaced & Displace \\
\hline 19. & Generation & Generate \\
\hline 20. & Apparently & Apparent \\
\hline 21. & Opportunity & Opportune \\
\hline 22. & Protection & Protect \\
\hline
\end{tabular}

Based on the findings, it can be said that there are 49 bound morphemes found in the article. 5 of them are derivational and 44 of them are inflectional. It can be concluded that bound morphemes are commonly used to change the words to make the sentences understandable and comprehendible by the readers easily.

\section{CONCLUSIONS}

After analyzing the article of Al Jazeera News, bound morpheme produces new words with a different meaning from the base word since the addition of derivational or inflectional helps to form a new word, and sometimes a new class of word. For example, inflectional of "Journal" into "Journalist". Journal is the base word that is a noun when adding suffixes -ist does not change the class of word, but the meaning changes from goods to a person. Bound morphemes are mostly used in texts in a newspaper to make the articles easy to read and understand by the readers. By analyzing the findings, it was found how words are formed to the new words with new meaning can be used to make the sentences understandable and comprehendible easily by the readers.

\section{REFERENCES}

Adisutrisno, D. W. (2013). English Morphology. Magister Scientiae, 33(33), 1-20.

\begin{tabular}{|l|l|l|}
\hline 23. & Calling & Call \\
\hline 24. & Especially & Especial \\
\hline 25. & Bloody & Blood \\
\hline 26. & Seriously & Serious \\
\hline 27. & Wounded & Wound \\
\hline 28. & Registered & Register \\
\hline 29. & Recruited & Recruit \\
\hline 30. & Nearly & Near \\
\hline 31. & Exploitation & Exploit \\
\hline 32. & Documentation & Document \\
\hline 33. & Displaced & Displace \\
\hline 34. & Poverty & Poor \\
\hline 35. & Starvation & Starve \\
\hline 36. & Married & Marry \\
\hline 37. & Relentlessly & Relent \\
\hline 38. & Suddenly & Sudden \\
\hline 39. & Running & Run \\
\hline 40. & Electricity & Electric \\
\hline 41. & Totally & Total \\
\hline 42. & Fighting & Fight \\
\hline 43. & Failed & Fail \\
\hline 44. & Influence & Influent \\
\hline
\end{tabular}

Aronoff, M., \& Fudeman, K. (n.d.). What is Morphology?

Best, J. W., \& Kahn, J. V. (1995). in Education.

Blevins, J. P., Morphology, W. I., Maiden, M., Anderson, S. R., Corbett, G., \& CarstairsMcCarthy, A. (n.d.). Praise for What is Morphology?

Jakarta, A. B. A. B. S. I. (2018). AN ERROR ANALYSIS ON THE USE OF SIMPLE PAST TENSE AND, 3.

Khan, S., Akram, W., \& Khan, A. (2016). Functions of Inflectional Morphemes in English and Pashto Languages, 3(1), 197216.

Kusumawardhani, P. (2018). the Error Analysis of Derivational Morphology in Efl ' S English Narrative Composition, 2(1), 2. https://doi.org/10.26858/ijole.v2i1.4857

March, H. D., Author, T., Reserved, A. R., Development, P., Street, M., \& York, N. (2014). English, Azerbaijani, and Persian Languages: A Comparative Study, 3(1), 593-614.

Nurngaini, I., Hastuti, D. P., \& Andriani, R. (2019). Derivation And Inflection Word Formation Used In Al Jazeera News, 11(2), 151-158.

Sukmacahyadi, D. (2018). An Analysis of Inflectional Affixes on English Department 
Students ' Undergraduate Thesis Abstracts. Journal of Research \& Method in Education, 8(5), 17-21. https://doi.org/10.9790/73880805031721

Thesis, A., Henisah, R., \& Faculty, T. T. (2021). AN ANALYSIS OF USING DERIVATIONAL AND INFLECTIONAL MORPHEMES ON JOKO WIDODO' S SPEECH AN ANALYSIS OF USING DERIVATIONAL AND INFLECTIONAL MORPHEMES ON JOKO WIDODO' $\mathrm{S}$ SPEECH. 